\title{
System Design for People Dealing with the Bureaucratic Liminal Space Case Study: Family Member that Take Care of Terminally Ill Family Member in Israel
}

\author{
Schwarz-Lis Ora \\ Bezalel Academy of Art and Design \\ Persov Elad \\ Bezalel Academy of Art and Design
}

\begin{abstract}
A $23 \%$ increase in the number of family members that find themselves as care providers has been documented throughout the last decade. Accompanied is a family member who accompanies any terminal ill family member. This project examines a system-design solution for the helplessness and obstacles that the Accompanied experiences. This project found that the most efficient service for alleviating the Accompanied's helplessness is a Case Facilitator (CF) who has expert knowledge of the health bureaucratic system and Interpersonal skills. This system-design solution could also solve similar problems for any person who find themselves dealing with liminal bureaucratic spaces.
\end{abstract}

Keywords: Death, Service Design, System Design, Liminal Space, Palliative Care

\section{INTRODUCTION}

The aim of this project is to make things easier for the Accompanied. In this project, I use Accompanied to refer to a family member who accompanies any terminal ill family member at some time during their illness. My motivation is based on personal experience. During 2017, I accompanied two terminally ill, family members. Unfortunately, caretaking duties will reach us all. This research can apply to terminally ill individuals, elderly parents, or children with disabilities. In this project, I focused on families with a terminally ill family member. There is a lack of research on the influence of the imposed responsibility on the Accompanied.

We repress end of life issues. We are afraid of "the impossibility of further possibility" (Yalom, 2008, p. 59). This is one of the reasons why there are no answers for end-of-life challenges. There was an art still life trend, memento mori (Some examples in Appendix A), the purpose of which was to remind us not to forget that one day, we are going to die. Knowing about death will help us deal with it when it arrives and will help us to live better lives.

Caring for family members has several aspects. There are psychological aspects, including the fear of death, medical aspects include palliative care, and taking care of patients' pain and suffering when the "battle against illness is ended" (EE - See Informants layout Appendix B). Along the many aspects of end of life process, families face ethical and legal limitations, together with social, spatial and cultural 
considerations. There are multiple bureaucratic systems to be dealt with, which include duplicate services for the Accompanied in many organizations. Finally, we must consider what happens to the Accompanied and their support system after the death of a terminal ill family member.

This research utilized qualitative methods, including 20 interviews (See Informants layout appendix B), three observations (See Observation layout appendix C), two conferences, and self-documentation. One of the Accompanied duties is to ensure the quality of life of the terminally ill family member, despite their limited life expectancy. The conclusion of this research suggests that a Case Facilitator (CF) will allow Accompany to do it. One of the CF's functions is being with Accompanied in the obscure liminal space where there is no clear responsible service provider. The liminal space is "when you are between ...if you are not trained ... how to live with ambiguity..." Richard Rohr (Barron, 2013). CF recognizes liminal space potential and with this knowledge, the CF will be able to provide the most accurate and holistic service that the Accompanied needs. The CF will help the Accompany "...tolerate the anxiety and develop the faith that things will take shape" (Barron, 2013).

This potential solution could help the Accompanied during and after the accompany process. This solution has been tested and approved with Accompanied, end of life social workers, palliative care nurses, and hospital manager. Nevertheless, actual pilot program is still to be conducted. The CF system design solution, may be found useful not only in this case of Accompanied terminal ill family member, but also in many scenarios in which people find themselves lost in liminal space, such as parents of disabled children, the unemployed, migrants, and children to elderly parents.

\section{FIGURE 1 ACCOMPANIED'S FEELINGS EXPRESSED VISUALLY}

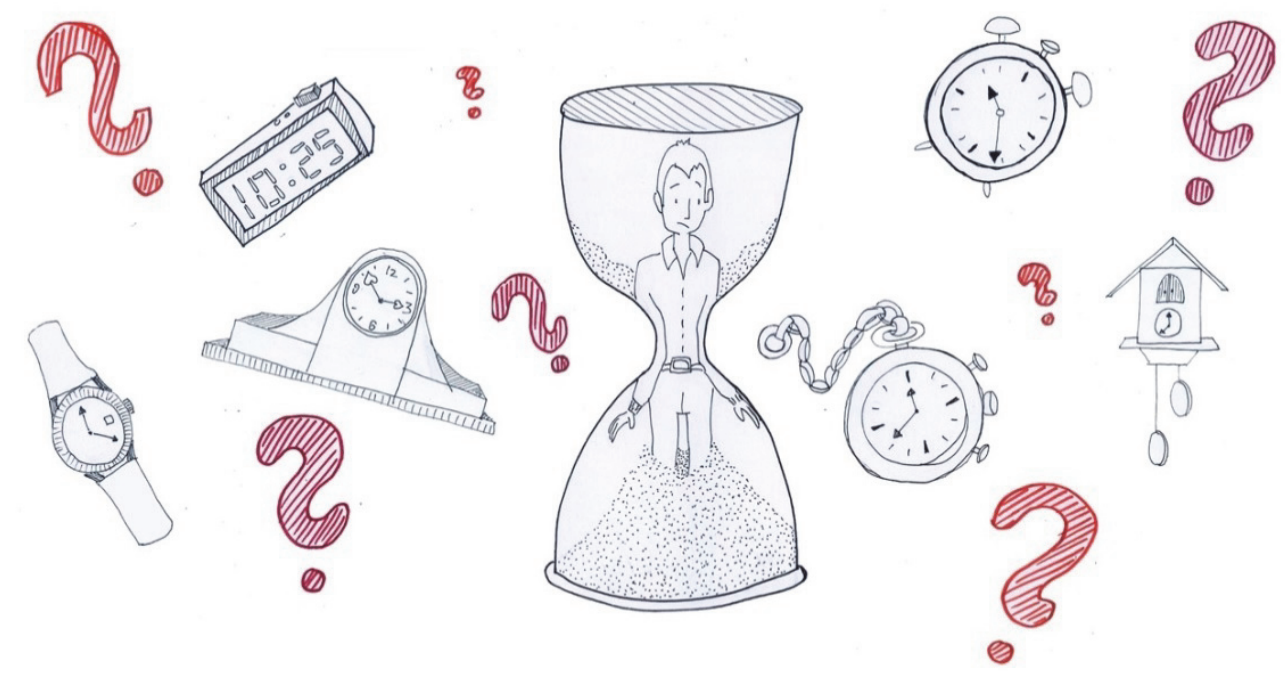

\section{LITERATURE REVIEW}

The purpose of palliative care is to maintain the quality of life and prevent suffering for terminally ill patients. Today's updated palliative care field is meant to maintain the quality of life and prevent suffering for all patients. This project can be included under the third sustainable development health care goal of UNA 2015-2030 (United Nations Association of Philadelphia), to "ensure healthy lives and promote well-being for all at all ages." It could be also included under 2018 trends, such as "precision treatment " (PSFK Originals, 2017), to create the most accurate personal treatment to suit each patient's lifestyle.

The 2018 trends relate directly to the patient. They show the beginning of the understanding that patient treatment is complicated and requires additional involvement besides the medical professional 
team. The unprofessional caregiver, Accompanied, is missing from these trends. In Israel, "the patient is not hospitalized alone;" (LW) the family members tend to stay in the hospital during the hospitalization time.

This literature review contains academic articles, media resources such as TED and YouTube videos, documentaries, and family radio programs debating end of life issues. It also includes information from participation in two conferences - one about palliative care, and the other about end of life ethics issues. This chapter will review the main issues that were found in the literature review. These are:

1. Making death a dignified end of life

2. Legislation

3. Palliative care

4. Place of death

5. Contact with the bureaucracy system

6. Multiple non-profit organizations

7. Family physician status

8. The joy of professional caregivers

\section{Making Death a Dignified End of Life}

According Epicurus, suffering is the continuous fear of death (Yalom, 2008). Physicians are not trained to stop searching for healing options for their patient (Gawande, 2014). Hospitals are designed for diseases, not patients. In the video What Really Matters at the End of Life (Miller, 2015), BJ Miller proposes "to invite design thinking to this subject (end of life)," as there is a lack of attention to the design of palliative care medicine. Some physicians are not exposed to this field during their studies. BJ Miller is a palliative care physician who criticized hospital design and invite designers to redesign hospitals based on the thought of how they would like to die.

Palliative care nurses find that death is a process, like birth (Missoula Community Access Television, 2014), and not an event. So, how might we turn death to a dignified end of life (LiLach, 2017)? How should we prepare for death, as eventually all of us are going to die, and there is no second chance to be prepared to die (The FEED SBS2, 2016)? Based on the literature, palliative care nurses have the tools and abilities to turn death into a dignified end of life.

\section{Legislation}

The definition of terminally ill in this project was any patient that will die from their disease. For example, this project includes the Accompanied of patients with chronic diseases (Kol-Zchut, 2017), different stages of cancer (Only cancer stage four is defined as terminal), and ALS. The definition of terminally ill is flexible and depends on medical development. During the $80 \mathrm{~s}$, HIV was defined as a terminal illness (Pierson, Randall, \& Patrick, 2002) until the development of medical treatment. During 2017-18, some laws were updated in Israel, including benefits for the Accompanied, but most of the Accompanied are not aware of laws existence (RL).

\section{Palliative Care}

Palliative care, as one nurse said, is "specialized with the dying" (Haelo, Voices From the Frontline, 2016). Professional palliative care accompanies the patient by guaranteeing their quality of life as much as possible until their death. Professional palliative care uses different tools, such as listening (Starkman, 2018), guiding family through the process of forgiveness, observing the patient without judgement (Missoula Community Access Television, 2014), accompaniment rather than treatment, preventing patient loneliness, and servicing patient needs - "we just travel him" (Dying at home - The Feed, 2016). These tools can also be used by the Accompanied. The support volume of palliative care will be based on the patient's disease stage, including after patient death. 


\section{FIGURE 2 \\ TRADITIONAL PERCEPTION OF PALLIATIVE CARE TREATMENT (TOP) VERSUS NEW PERCEPTION (BOTTOM)}

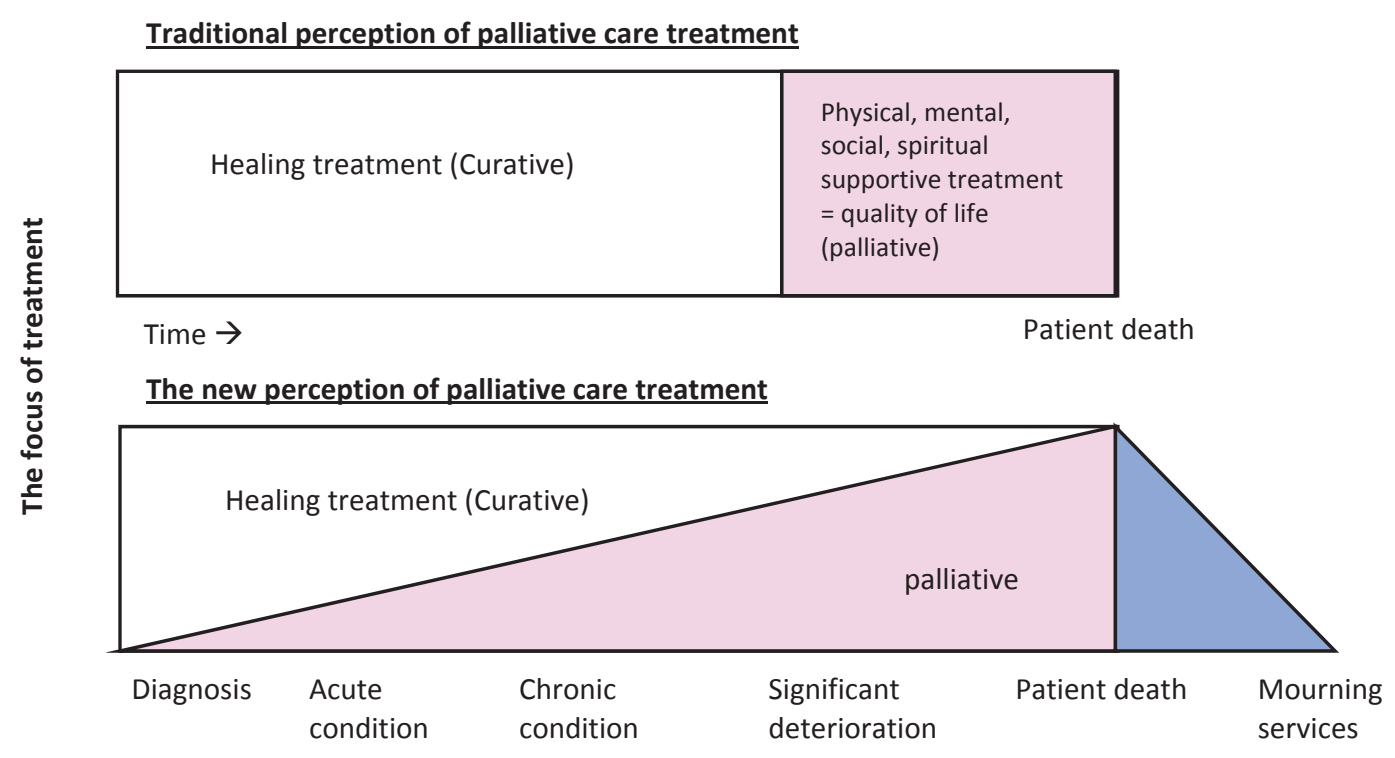

(Bentur, 2005)

Place of Death

FIGURE 3

THE PLACE OF DEATH CIRCLE OF CHANGES: FROM HOME, TO THE HOSPITAL, TO THE HOSPICE, BACK TO HOME

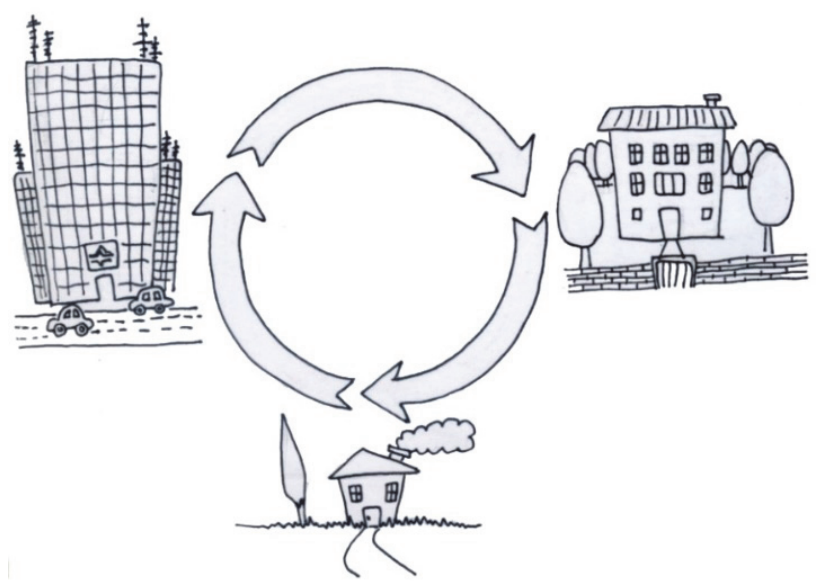

In the past, the whole circle of life occurred at home. The exposure to death was extremely high (Molloy, 2015). Today, most people die at hospitals, although some choose otherwise (For example, in Australia, 70\% of patients choose to die at home (The FEED SBS2, 2016), while only 14\% actually died at home; more than half of patient are dying in hospitals. In the USA (Gawande, 2014) only 27\% of patients died at home, which is high, because most of these patients did not have time to reach the hospital). When death is not easily visible, the exposure to it is low. This is one of the reasons that people are afraid of death. 


\section{Contact with the Bureaucracy System}

Caring for a terminally ill family member requires involving several authorities such as: healthcare, social systems, municipal services, religion, and medicine. There is a lot of paperwork required to coordinate between these functions. The services needed by the Accompanied are located in the liminal space created between the responsibilities of all authorities' services providers. There is no sole entity that has budget and staff to provide the holistic accurate need of the Accompanied. Instead of working effectively with the Accompanied, when the healthcare system and the authorities are most needed, they are adding difficulties. Daniel Blake's (Loach, 2017) neighbor told him that the system will kill you. Does the system aim to kill patients more quickly, or is doing paperwork an escape option for the Accompanied?

\section{Multiple Non-profit Organizations}

Many organizations aim to support patients and their families, yet many organizations provide similar services (For example, one organization was established in 1990 to help cancer patients between the ages 0-25 and their families. Another organization was established in 2009 with exactly the same purpose). The Accompanied has various organizations that can help them. Duplicate organizations, however, can cause a waste of resources on both sides. One organization supplies multiple services that can be supplied by other organizations, instead of providing a unique service. The Accompanied wastes precious time figuring out the differences between identical services supplied by different organizations.

\section{Family Physician Status}

Why should not the family physicians be their patients case manager? The family physicians will accompany the patient from the first news of terminal illness until the end. Family physicians are familiar with their patient's medical history. The family physician can connect different authorities and healthcare system information. "Incidents are not usually caused by a single decision or action... it is caused by dynamic interactions between people, tasks, technology and working conditions... management, policy, regulation..." (Gyuchan, 2017). Healthcare incidents are the third cause of death in world (Mozer, 2018). "In a perfect world, family physicians should manage patient cases and needs" (Levi, 2018). Family physicians connections will prevent incidents and help provide better service to the patient and the Accompanied (Reznik, 2017).

\section{The Joy of Professional Caregivers}

Professionals palliative caregivers, although their professions expose them to death with great frequency, were found to be satisfied and happy people. "I think I am one of the happiest physicians in the world" (Nir, 2013); "we are all happy" (Steinmatz, 2016). This happiness was found to exist across the field; every professional caregiver I spoke with expressed their satisfaction despite the difficulties.

\section{RESEARCH LAYOUT}

This research used human-centered design management tools to find how the Accompanied can use their limited resources to improve the quality of their lives. The field research was based on qualitive tools such as interviews, observations, and seminars.

\section{Informants}

Professional informants were chosen for research. These included social workers, psychologists, physicians, and palliative care nurses. Nonprofessional informants included the Accompanied, volunteers in an organization that transfers information to elderly patients, researchers in this field, and company/application founders. Informants layout include 20 interviews (For Informants layout table see Appendix B). 


\section{Observations}

Three observations (See Observation layout Appendix C) of an up-to-date medical information center, a medical center oncological day care center, and a hospice were done. All observations included interviews.

\section{Research Limitations}

I could not interview the Accompanied mainly from ethical reasons. In addition, the Accompanied denied any connection to terminal illness. As long as the patients were alive, they maintained a hope that it was not terminal. Further research needs to be conducted to evaluate the proposed solution viability and integration with local systems.

\section{Stakeholders}

Hospitals, workplaces, health insurance and healthcare systems are the project's central stakeholders.

\section{Prototype}

Mapping (See Appendix D) and analysis of overall research findings suggested that the following five insights are the most critical for the Accompanied:

1. Diagnosis of terminal illness

2. Overwhelming information

3. Confronting bureaucracy

4. Release from hospital crisis

5. The kick (IR), 17 days on average (Nir, 2013), before death

At the last point, when the physicians announced there was nothing else they could do, they had the patient choose between hospital hospice and home hospice. Time limitations forced the Accompanied to use their resources efficiently. Focusing on this point shows that many changes are required for patient home care. A two-room apartment was drawn and shown to the Accompanied. They were asked to state which changes needed to be done to make the apartment suitable for home hospice. It was found that:

1. Home hospice is not available for all and required a special setting

2. Part of the information on how to prepare for home hospice was known retrospectively

3. The kick can be softened by advance preparations

4. Getting the sketch done by a professional made it possible for the Accompanied to prepare their home 
FIGURE 4

PROTOTYPE APARTMENT SKETCH BASED ON FIELD RESEARCH

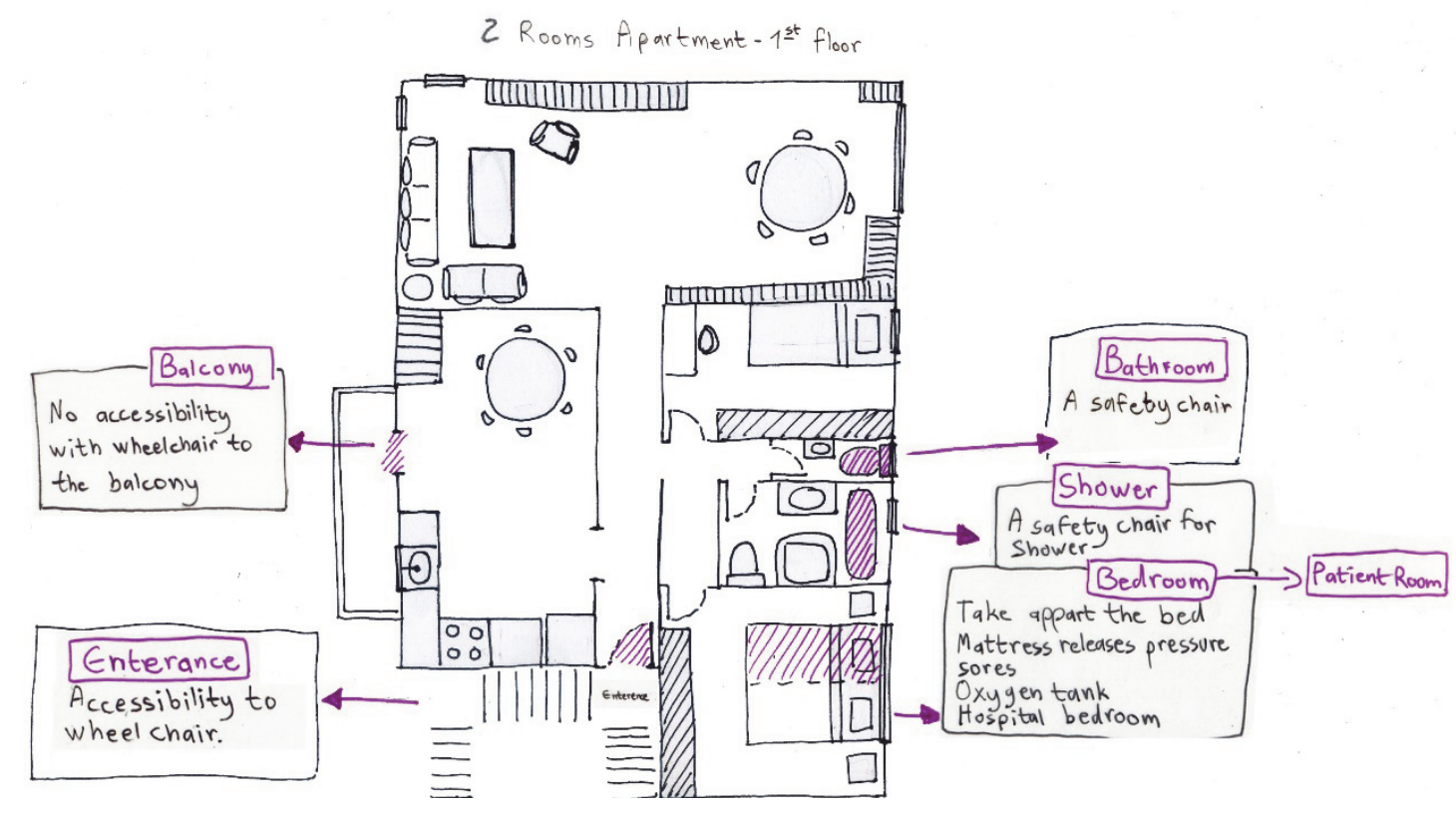

FIGURE 5

PROTOTYPE APARTMENT SKETCH WITH ACCOMPANIED NOTES

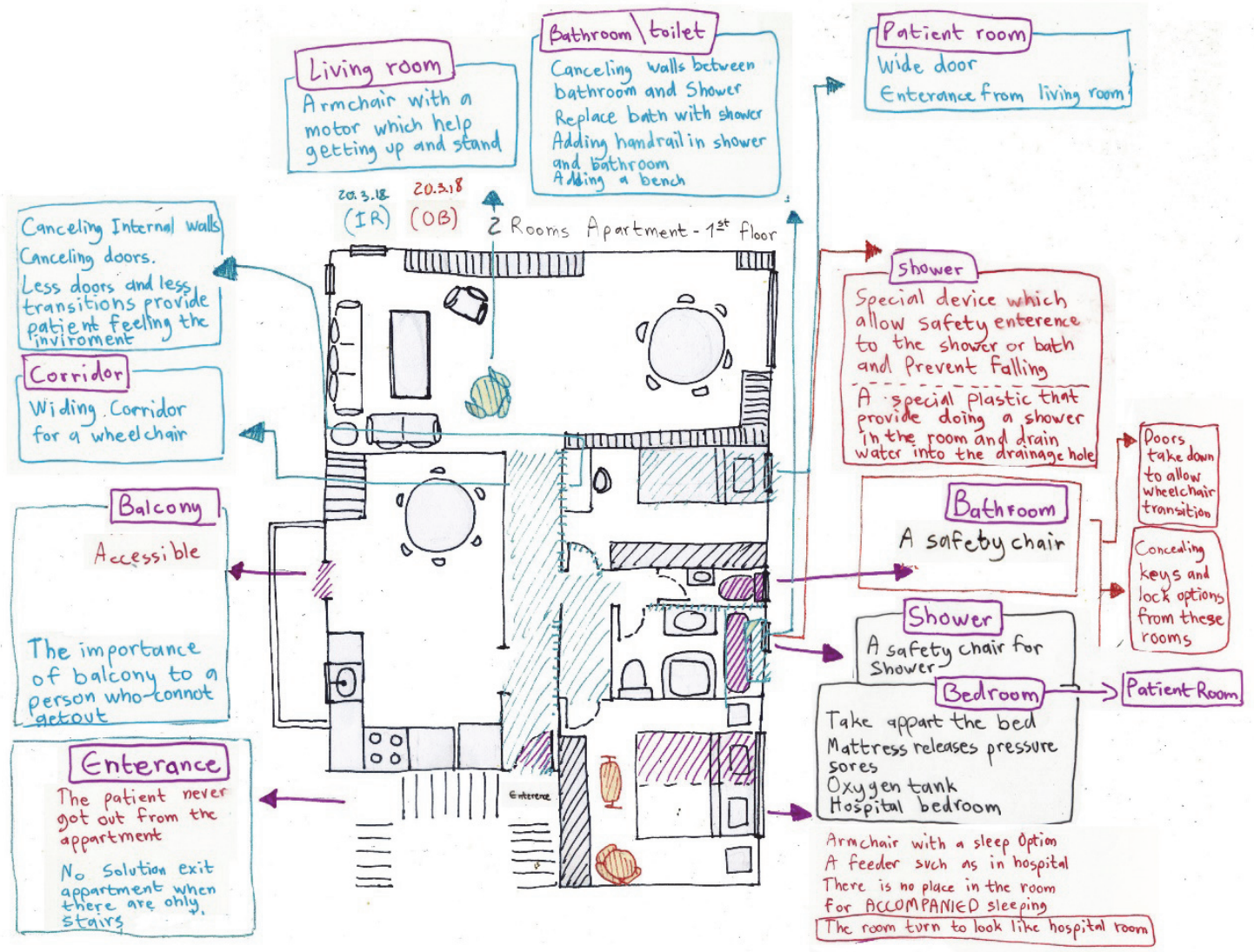

Journal of Strategic Innovation and Sustainability Vol. 14(6) 2019101 
Three different prototypes were made during this project. Two of them are detailed above (Experience map and apartment sketches). The last prototype was multiple storyboards strips (See Appendix $E^{\text {) }}$ which were presented to the informants. The methodology behind the storyboards is the visualization of informants in a familiar situation, which allowed them to freely express their thoughts, which created deep insights. Five storyboard strips were presented to the informants. Each of them showed one critical pain point. These storyboards were presented based on a chronological experience map. They were presented to five informants in four interviews.

\section{SELECTED RESEARCH FINDINGS}

\section{Caregivers Make Up a Quarter of the Labor Market in Israel (RL)}

The term caregiver refers to any family member that takes care of the elderly, ill, or disabled. This project refers only to the Accompanied. $25 \%$ of employees are caregivers (RL). $60 \%$ of them hide the fact they are caregivers. 3.7\% of them quit their job. "Based on USA data, caregiver employees cost $\$ 3,000$ to the workplace because of absent work days, quitting their job, recruiting, and training new employees" (Saragusti, 2017). Most caregivers are around 45 years old, the peak of productivity (Saragusti, 2017). In the last decade, caregiver numbers rose by $23 \%$ (Elizera, 2018). The Accompanied reported that they were occupied with patient care during work hours. "Being a caregiver is an additional career" (Saragusti, 2017). There are two ways to help the Accompanied:

1. Supply formal services, such a professional daily caregiver.

2. Supply services such as money or mental support.

\section{The Accompanied's Status in the System}

Being an Accompanied has emotional, health, economical, and social costs. It is not a role people choose. Most of the time, the Accompanied was given this role without any qualification or preparations. There is no "one adjusted rule" for Accompanied (Reznitsky, 2015). Therefore, it is challenging to find one service that fits all Accompanied. "It is time to develop ethical rules to help the Accompanied to take their place in the medical decisions of their family patient. These rules should be adapted to state, community, and family values" (Reznitsky, 2015).

World trends recognize the special status of the Accompanied. In 1999, the UK declared a national strategy regarding the Accompanied (Brodsky, Resnizki, \& Citron, 2011). Role recognition opens an opportunity to provide holistic and accurate services. An example of how "a little service can support the Accompanied" (RL) is the Hertz pilot service (Hertz drivers volunteer to transport disabled patients to their hospital treatment and back home. This service gives the Accompanied some breathing space).

\section{The Liminal Space Between Authorities Add Difficulties to the Accompanied}

Hospital prescriptions do not contain enough medicine (IR); this is one of the issues with the system. There is no synchronization between different systems and authorities in the liminal space, such as hospitals and community healthcare systems (IR). The Accompanied spends a lot of their time filing papers and chasing signatures (OB). There is a danger that charlatans might use the system's weaknesses to gain unfair advantage or commit fraud.

\section{Family Physician as a Case Manager}

The patient is surrounded by a professional team and the Accompanied. There is a need for holistically, effectively adjusted management. Family physicians are the most familiar with the patient and are able to minimize incidents during treatment. The system does not define the family physician as a case manager, but some family physicians act as case managers, despite not having the resources to do so (palliative seminar, 2017). Due to the missing case manager function in the system, the Accompanied find themselves acting as case managers (ID). The Accompanied should not be case managers, since they do not have the required knowledge, experience, or understanding. The Accompanied should focus on accompanying their family member and not managing their case. The family physician should be the case 
manager. Israel Medical schools should include improved content about terminal patient care, including the Accompanied (DS).

\section{Post Mortem Opportunities}

After the death of the terminally ill, the Accompanied still need support (ID). Suddenly (It will always be sudden, no matter how much you prepare for death), the Accompanied find themselves unoccupied. After death, they would use their free time to do good for future Accompanied. For example, developing an application with information for cancer patients (ID), providing information by volunteering (HB), and establishing organizations to supply caregivers' needs (RL). These research findings supplied many opportunities. The challenge was to choose the best opportunity to fulfill most Accompanied's needs.

\section{PROJECT PRODUCT}

The case facilitator (CF) is a new professional. The CF will accompany the Accompanied from terminally ill diagnosis, through the liminal space between different authorities, up to and after death. The $\mathrm{CF}$ will assist the Accompanied in using their limited resources in the most efficient way and will minimize the Accompanied's helplessness, especially when time is critical.

\section{Goals}

1. Maximize the accessibility of relevant information in the liminal space.

2. Minimize wasting time and money for the Accompanied and the system, especially when there is Mission overlap because of duplicate organizations and services.

Israel healthcare system recognizes the importance of continuous treatment, but such treatment does not exist. There is a lack of hospital beds (RR), but it is forbidden to release patients from the hospital to home if their home is not adjusted for the patient's condition. The nurses are in a conflicting situation-if they release patients from the hospital, the hospital will save money, but they are not allowed release patients to non-suitable homes. It is not surprising when the current patient-nurse standardization is based on data from 22 years ago (RR).

FIGURE 6

\section{EXAMPLE OF PATIENT COMPLEXITY (LEFT TO RIGHT): A MAN REACHES TO HIS 90TH BIRTHDAY; HE MAY DEVELOP DIABETES, WALKING ISSUES, OR/AND DAMAGED HEARING, OR/AND BE DIAGNOSED WITH CANCER}
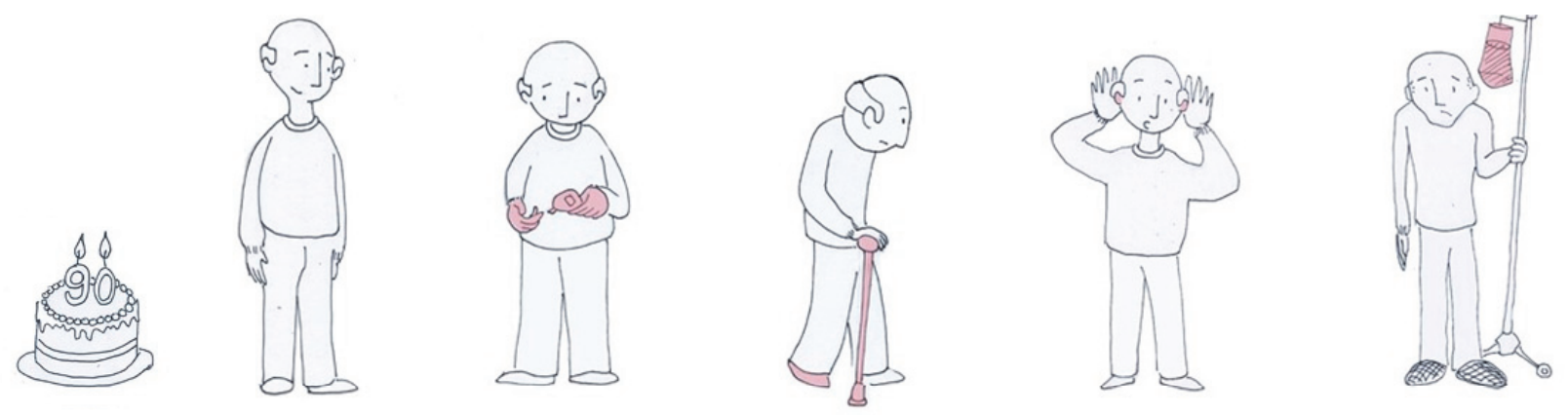

\section{The Solution}

The Case Facilitator (CF) solution can help solve the complexity of Accompanied process. The CF is with the terminally ill patient family members from diagnosis. The solution will be presented by the following storyboard prototype. Let's join the CF, who is already familiar with terminally ill patient and 
family, during the 17 days (Nir, 2013) before patient death. The CF knows that this family could, with some arrangements, handle home hospice. The CF presents the two solutions, hospital hospice and home hospice, with their advantages and disadvantages.

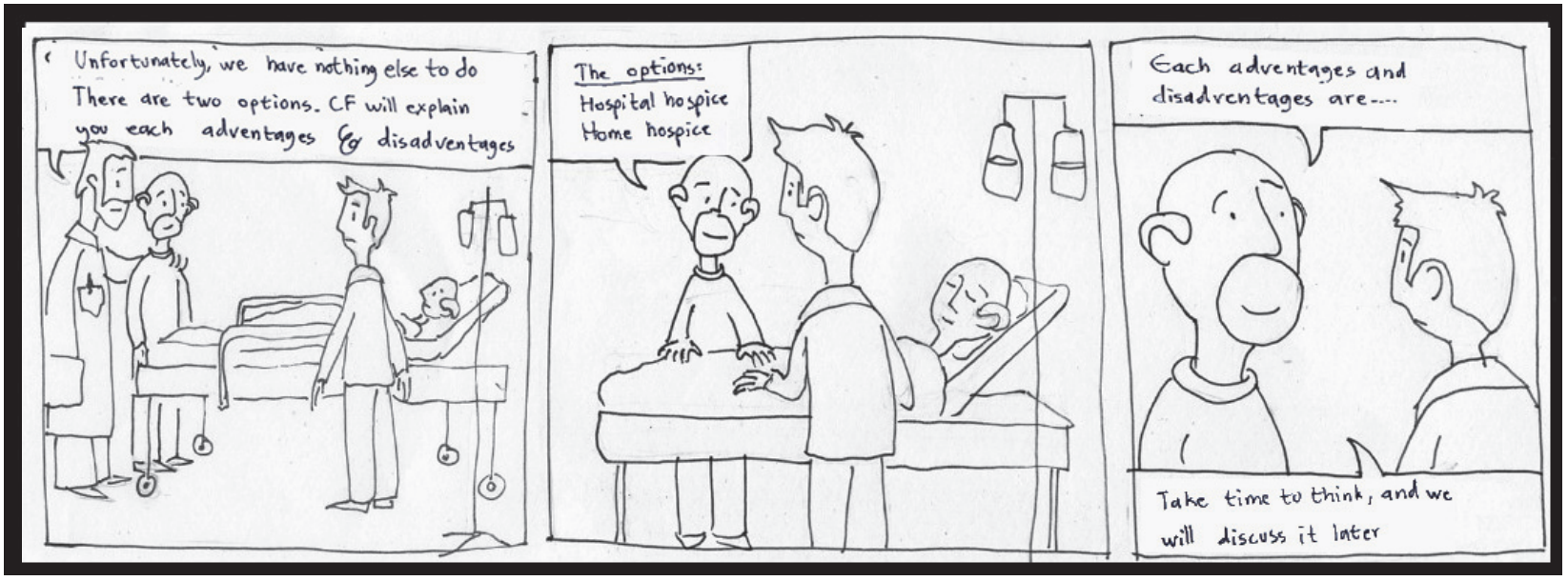

As part of this presentation, the CF takes the family to visit a hospice and answers their questions.

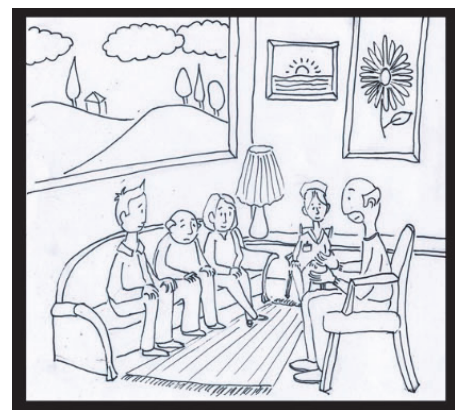

In addition, the $\mathrm{CF}$ explains the home arrangements they need to make, based on CF familiarity with their home. The family chooses home hospice.

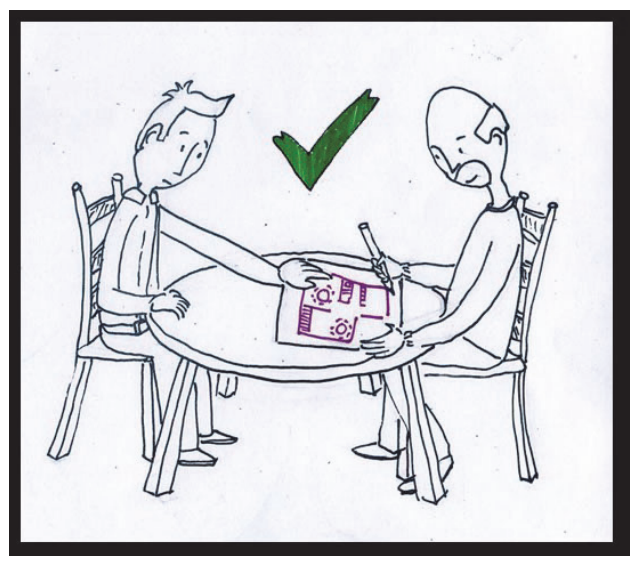

In coordination with the family, the $\mathrm{CF}$ orders equipment to make their apartment into a home hospice. The family receives the equipment order at home. 


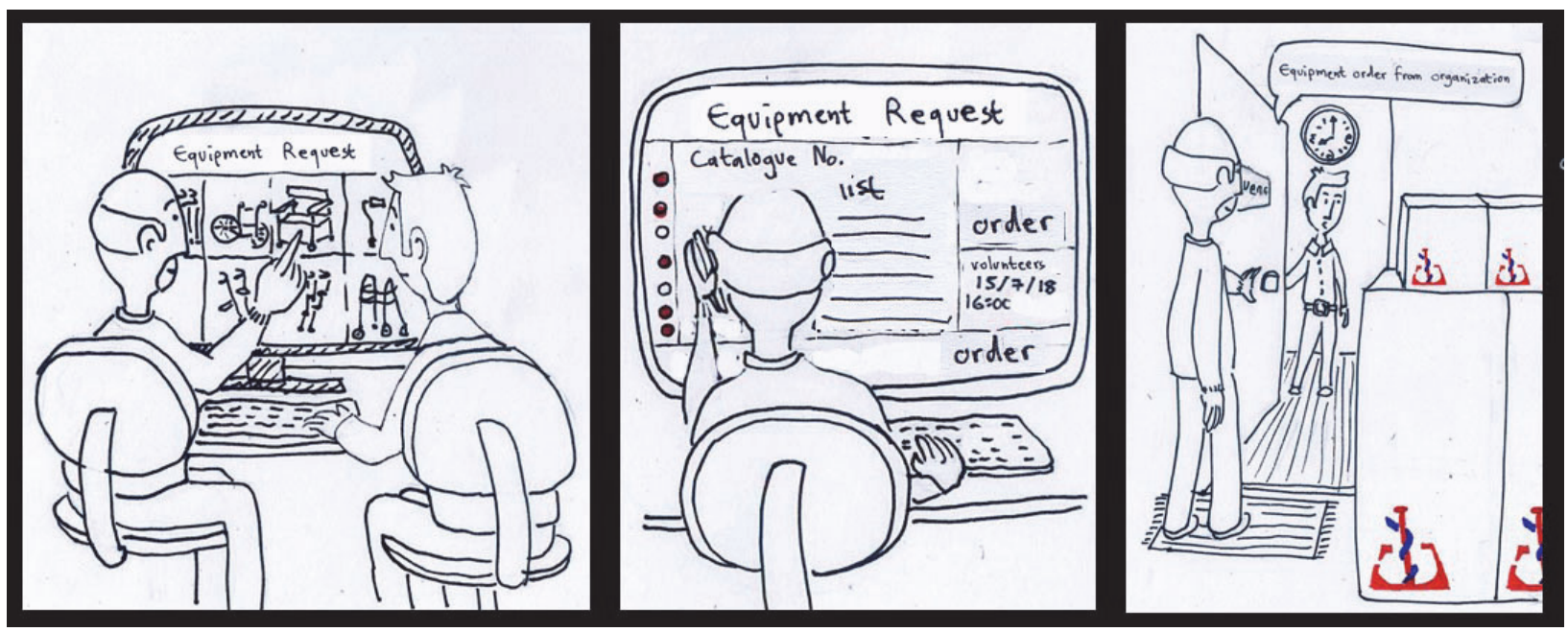

The CF checks the physician's prescription before releasing the patient. The CF is able to adapt the prescription with the physician and adjust the next 17 days (17 days on average (Nir, 2013), before death). This CF service prevents pharmacy visits by the Accompanied and lessens patient suffering. The CF collects the medicines.

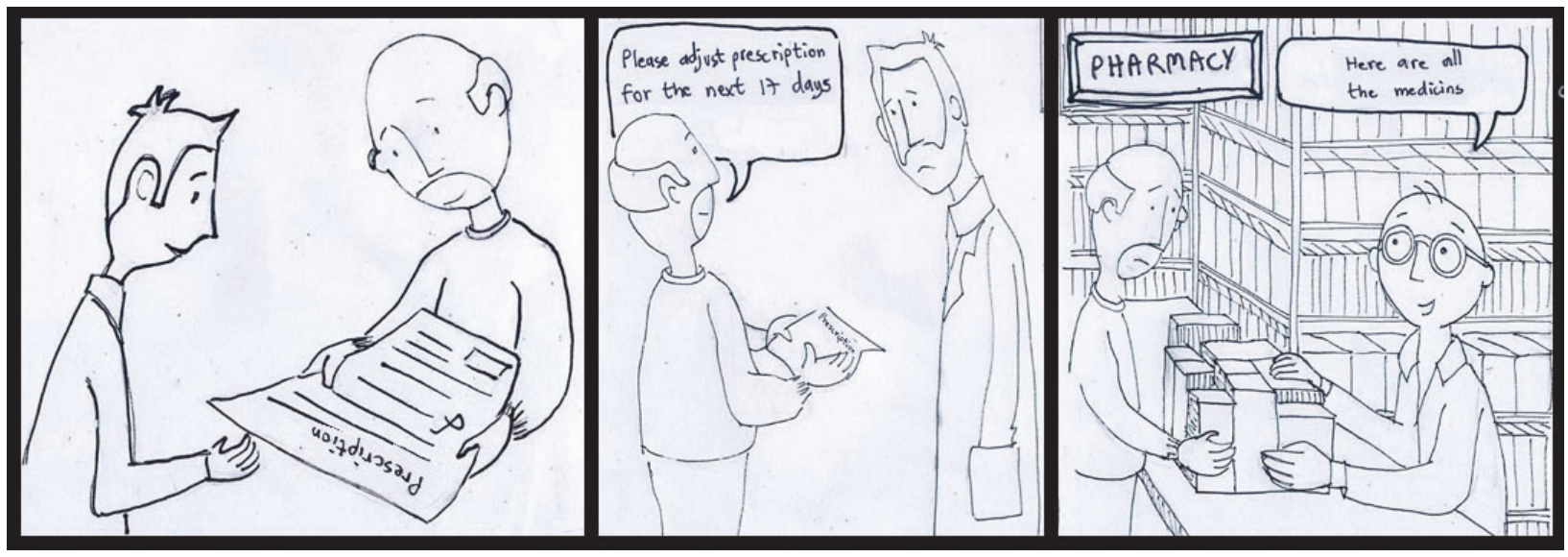

The patient arrives at home. The CF guides the family in connecting the patient to their equipment. The CF leaves, reminding family that they are available for them around the clock.

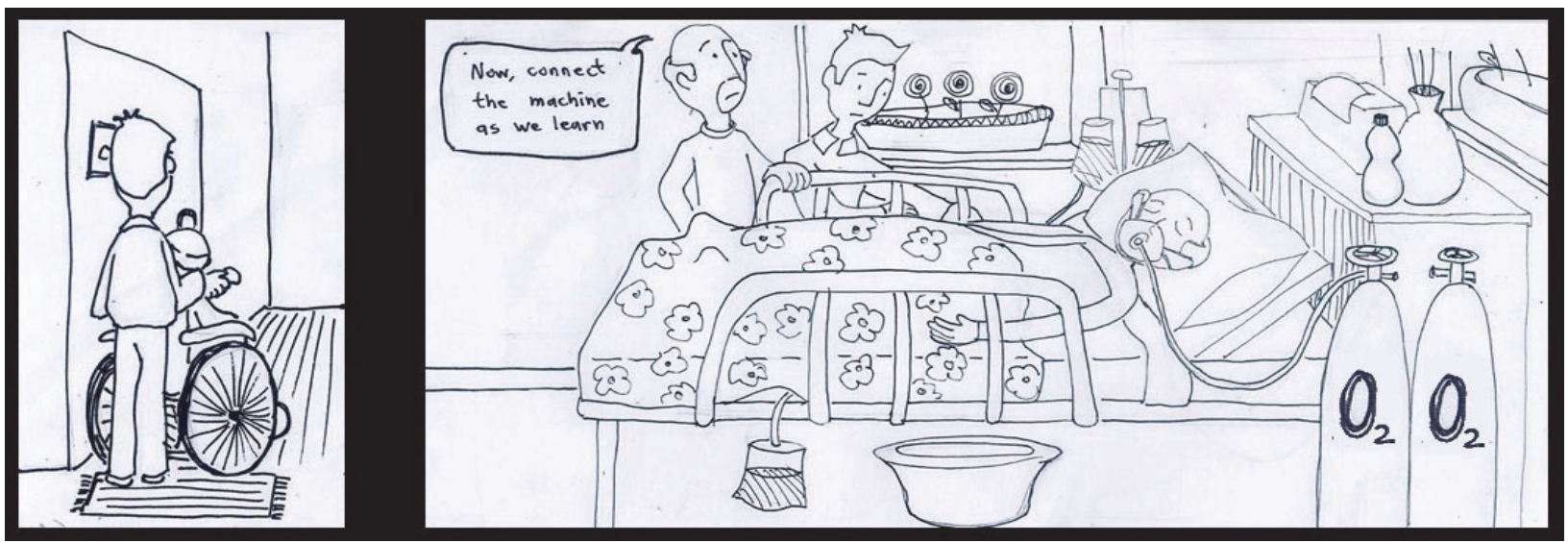


A few hours later, the Accompanied calls the CF about a medicine dosage issue. There are two optional scenarios at this point:

1. An experienced $\mathrm{CF}$ is able to guide Accompanied by asking the Accompanied a few questions.

2. The CF does not have the information, but knows how to get it and with whom to consult. The $\mathrm{CF}$ tells the family they will get back to them with information after consulting. The family is already familiar with such a scenario from the past, therefore they are not worried. After a few minutes, the CF calls the family with the answer. The CF uses this opportunity to remind family that the hospital hospice solution always exists if they regret choosing a home hospice. This question and answer scenario occurs several times during these 17 days. If needed, the CF has backup from the CF center where they were trained.

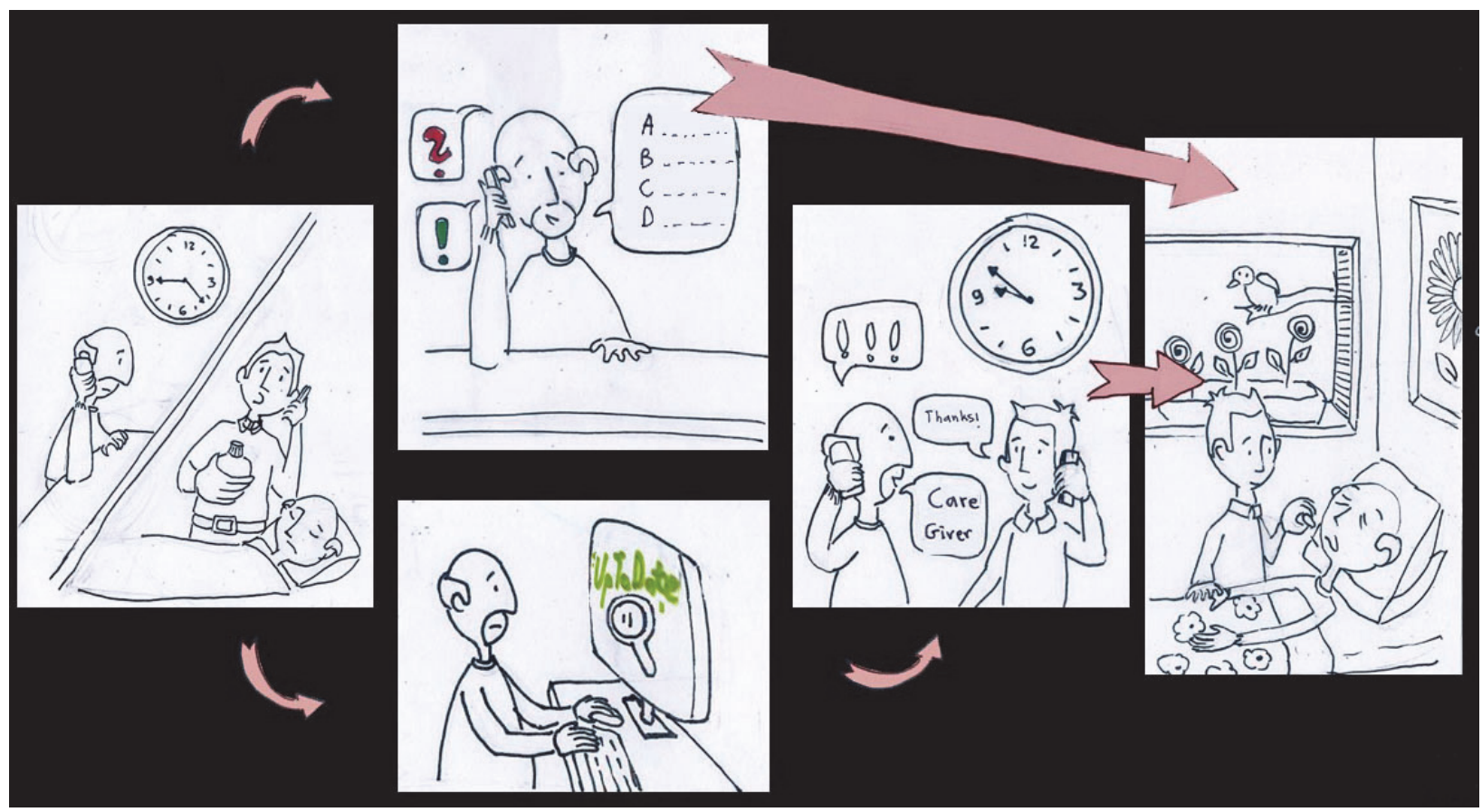

Based on the terminally ill patient's instructions, such as do not revive (DNR), the CF instructs the family on how to prepare for the day of death.

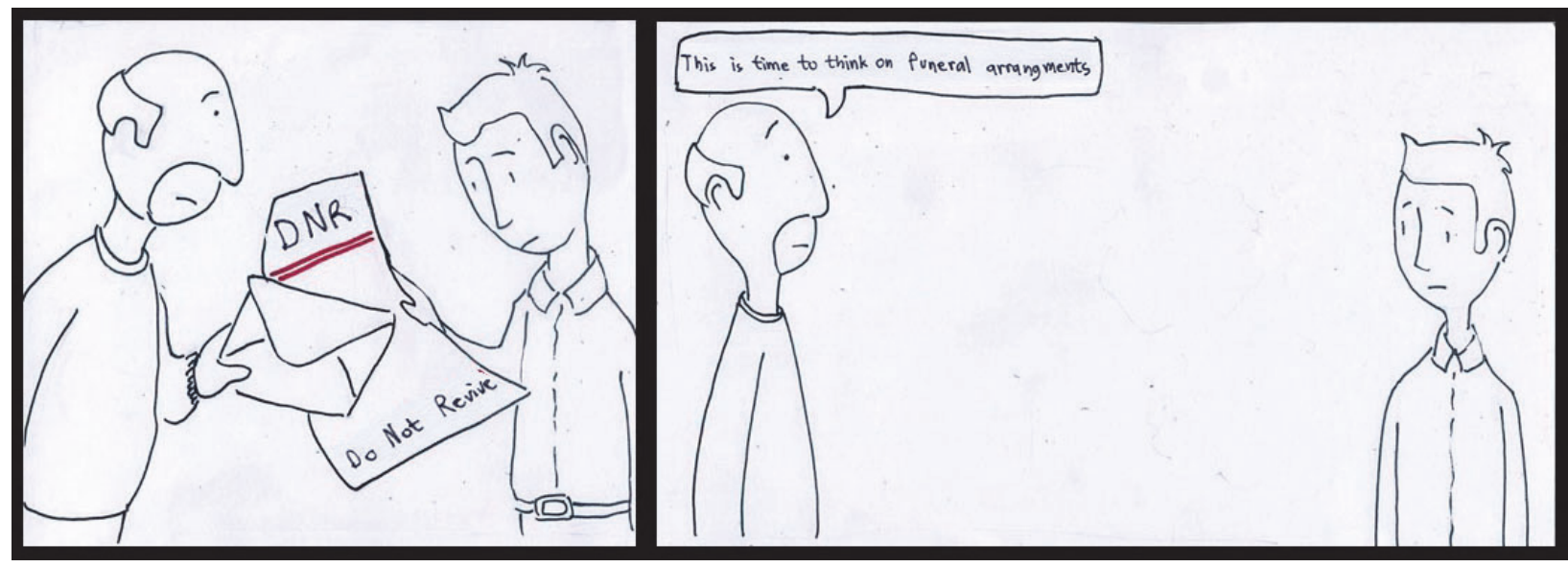

The day of death arrives. The family contacts the CF, informing them that the patient died. 


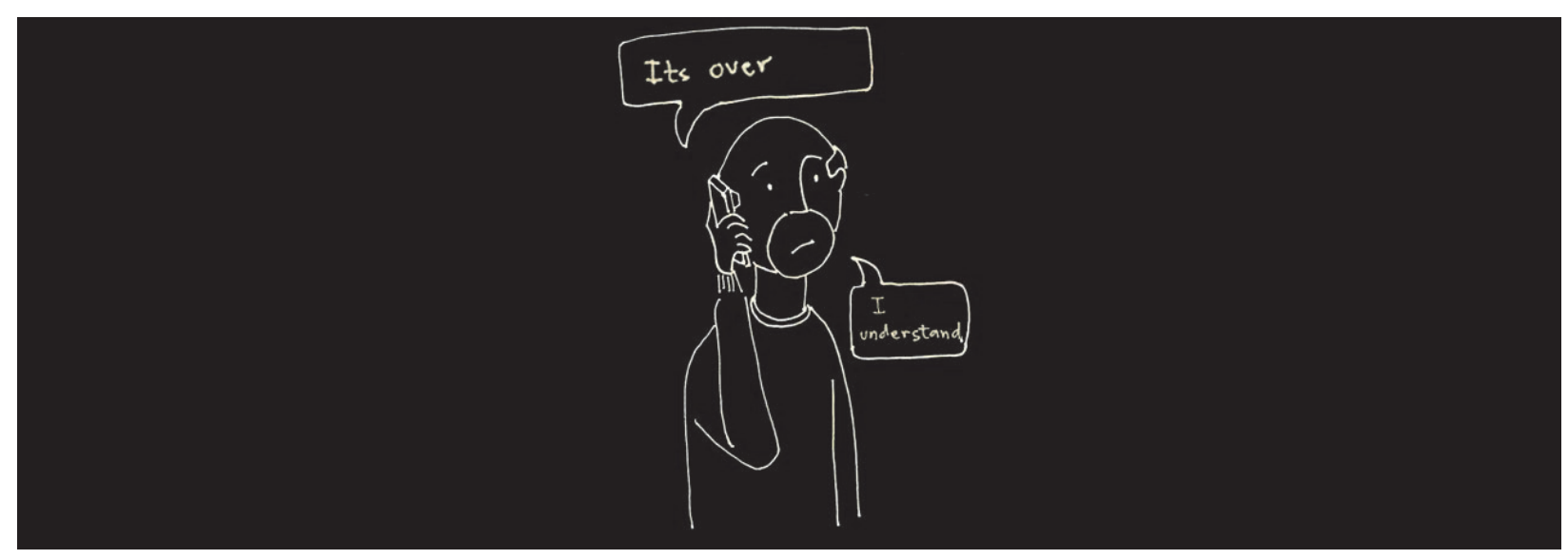

The CF helps the family organize the funeral. Following the funeral, the CF visits the family, providing information about the following days, verifying that the family has what they need, and reminding them that, although the patient has died, they are available for them. As time goes by, the CF's accessibility decreases.

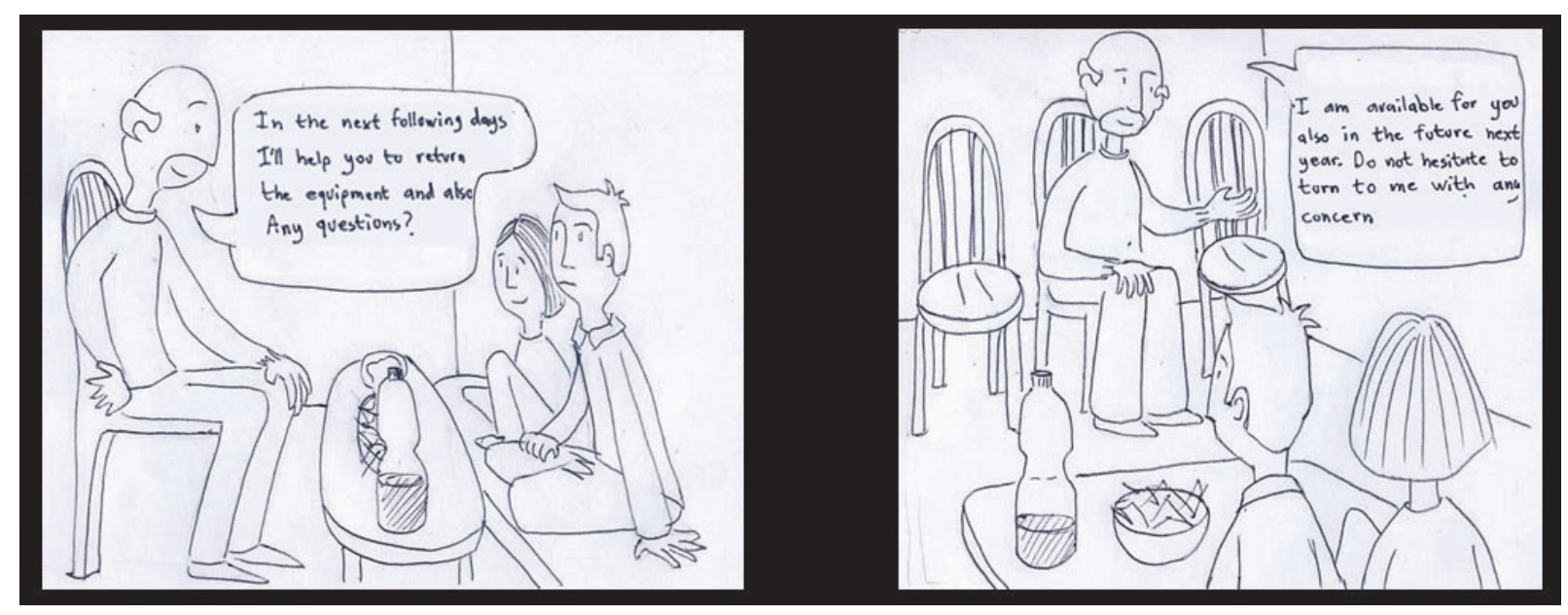

\section{Product Features}

CF qualifications should be:

- Interpersonal skills

- Holistic view of the patient and family

- Knowledge and experience in systems and the liminal space authorities, such as healthcare, social systems, municipal authorities, religion, and medicine

- Ability to find missing information

- Life and health system professional experience

- Service consciousness

\section{Following Step}

One of the CF solution's disadvantages is the additional factor in the liminal space, which already contains multiple authorities and functions. CF is a personal solution. Thus, it is not suitable for all. In fact, there are some advantages in dealing with liminal space (Barron, 2013) without CF. The aim is to experiment with the CF solution and to find a business model which answers the next questions:

- Will this service cost money or will it be free?

- Is it possible, based on current standardization in Israel, to supply this service? 
- Which authority will be responsible for the CFs (budget and management)?

- Who will train CFs?

If the $\mathrm{CF}$ solution is successful for the Accompanied, it could be scaled up to fit any person dealing with liminal space - for example, parents of disabled children, the unemployed, migrants, and children to elderly parents.

\section{SUMMARY}

The number of Accompanied is on the rise. Literature and field research have found several pain points when dealing with liminal bureaucratic space - the space of transition, waiting, and not knowing (Barron, 2013). The authorities are missing the potential of providing Accompany needed services, although there are multiple national and local authorities, which would like to provide the in between needed service.

Accompany pain points include the diagnosis of a terminal illness, missing knowledge, and dealing with routine while accompanying a terminally ill family member up to, and after the patient has died. At these points, the Accompanied is helpless. Therefore, how can the Accompanied continue their routine without reaching a breaking point? What will help the Accompanied? Will knowledge help? Or a specific person? Will the family physician as a case manager be the best solution, or other professionals?

The CF solution fulfills the project's goals. The CF will provide the Accompanied with the opportunity to maximize their limited resources. The CF solution was chosen because of the different levels of involvement potential throughout the entire process, rather than just the critical point 17 days before patient death (Nir, 2013). This is a holistic solution for all Accompanied pain points.

The CF solution was presented to the manager and nursing manager of the biggest hospital in Israel, and to a senior caregiver in the healthcare system. Research findings and the CF idea were approved by them. There is a similar solution for chronic diseases in the Ministry of Health work plan (Health, 2017; Health, Nursing administration 2017 work plan, 2017), yet it is not applied in the system.

The CF solution could help the Accompanied, who make up a quarter of the labor market (RL), by providing the needed "in-between" service that is most required at this time and moment by the Accompany. Authorities recognizing the Accompanied's liminal space experience, could use liminal space potential, for a better system service. The success of the CF in coordinating between systems and authorities, could be developed to other liminal space systems, which could solve many problems, for people who find themselves, dealing with the liminal space between many authorities.

\section{ACKNOWLEDGEMENT}

Illustrations by Schwarz-Lis Ora. 


\section{REFERENCES}

Bachrach, L. (2018, April 26). In memory of Talya Balilius-Talya oncology center was inaugurate for young women with breast cancer. Kol Ha-ir (All City). Retrieved from https://www.kolhair.co.il/jerusalem-news/52670/

Barron, C. (2013, June 4). Creativity and the Liminal Space. Retrieved from Psychology Today: https://www.psychologytoday.com/us/blog/the-creativity-cure/201306/creativity-and-the-liminalspace

Bentur, N. (2005). Services array for terminal ills patients. Terminal ills treatment, Haifa University. Haifa. Retrieved from http://slideplayer.com/slide/5080077/

Brodsky, J., Resnizki, S., \& Citron, D. (2011). Elderly family members treatment issues: treatment specification and caregivers support program. Myers-JDC-Brookdale Institute. Retrieved from https://brookdale.jdc.org.il/wp-content/uploads/2018/01/508-11-Issues-in-Family-Care-ESENG.pdf

Champagne, P. D. (n.d.). Still-Life with a Skull. museum in Le Mans, France.

Dying at home - The Feed. (2016, February 16). Retrieved from YouTube: https://www.youtube.com/watch?v=tUB_XnMLhuo

Elizera, R. (2018, December 12). Israel Central Bureau of Statistics Report: What is the Main cause of Death in Israel? Retrieved from YNET: https://www.ynet.co.il/articles/0,7340,L-5424457,00. html

Gawande, A. (2014). Being Mortal: Medicine and What Matters in the End. (PBS Frontline) Retrieved from http://www.pbs.org/wgbh/frontline/film/being-mortal/

Gyuchan, T. J. (2017, September 14). SystemsThinking - A New Direction in Healthcare Incident Investigation. Retrieved from YouTube: https://www.youtube.com/watch?v=5oYV3Dqe0A8

Haelo, Voices From the Frontline. (2016, December 5). Nurses on Death and Dying. Retrieved from YouTube: https://www.youtube.com/watch?v=j_FR-JVpnx8

Knox, M. (2017). End-of Life Care through Design: Visualizing Places of Death. (p. 201). University of Alberta.

Kol-Zchut. (2017, February 8). Right of chronically ill person. Retrieved from Kol-Zchut: http://www.kolzchut.org.il/he/\%D7\%97\%D7\%95\%D7\%9C\%D7\%94_\%D7\%9B\%D7\%A8\%D7 $\% 95 \% \mathrm{D} 7 \% \mathrm{~A} 0 \% \mathrm{D} 7 \% 99$

Levi, J. (2018, January 19). Hula reservation...impression from a hospital part A. Israel Today, weekend edition.

LiLach, B. D. (2017, November 5). Mishpaha Garinit, dignitas international day (family radio program).

Loach, K. (Director). (2017). I, Daniel Blake [Motion Picture].

Miller, B. J. (2015, September 30). What Really Matters at the End of Life. Retrieved from YouTube: https://www.youtube.com/watch?v=apbSsILLh28

Ministry of Health, Israel. (2017). Ministry of Health 2017-8 work plan. Ministry of Health. Retrieved from www.plans.gov.il/pdf2017/files/assets/basic-html/page-140.html

Ministry of Health, Israel. (2017). Nursing administration 2017 work plan. Ministry of Health.

Missoula Community Access Television. (2014, September 19). What Hospice Nurses Know: Dying and Afterlife Questions and Answers with panel. Retrieved from YouTube: https://www.youtube.com/watch?v=4gWytwh7U2k

Molloy, T. (2015, February 13). It's Very Hard to Come to the Realization That You're Dying. Retrieved from PBS: https://www.pbs.org/wgbh/frontline/article/its-very-hard-to-come-to-the-realizationthat-youre-dying/

Mozer, Y. (2018, June 23). Making mistake is human, Yariv Mozer docomentary film. (Kan 11 television channel). Retrieved from YouTube: https://www.youtube.com/watch?v=L_1T1XLTMzI

Nir, D. B. (2013, September 12). Mr. Death, an old acquaintance. Calcalist (Economic Journal). Retrieved from https://www.calcalist.co.il/local/articles/0,7340,L-3612064,00.html

Nurses on Death and Dying. (2016, December 5). Retrieved from Youtube: https://www.youtube.com/watch?v=j_FR-JVpnx8 
Pierson, C., Randall, J. R., \& Patrick, D. L. (2002). A good death: A qualitative study of patients with advanced AIDS. AIDS Care, 14(5), 587-598. Retrieved from Journal AIDS Care, Psychological and Socio-medical Aspects of AIDS/HIV.

PSFK Originals. (2017, August 8). PSFK Future of Health 2018 Webinar. Retrieved from YouTube: https://www.youtube.com/watch?time_continue $=4 \& \mathrm{v}=$ Daw777oTiGo

Reznik, R. (2017, November 24). Where my mother family physician disapears to? Israel Today, Health supplement.

Reznitsky, S. (2015). Final deseas: getting decissions in family unit, doctorat abstract. Retrieved from http://brookdale.jdc.org.il/publication/final-illness-decision-making-family-unit-doctoral-thesisabstract/

Saragusti, A. (2017, February 19). Who take care of caregivers family members? The hotest place in hell, independent journal magazine. Retrieved from https://www.ha-makom.co.il/project/generation-awomen-caregivers

Starkman, L. (2018, May 26). You do not have to hospitalize: the doctor who brought treatment to home. TheMarker. Retrieved from https://www.themarker.com/consumer/health/.premium-1.6114887

Steinmatz, M. (2016, April 29). The woman who heard thousands people last breath. Walla News. Retrieved from https://news.walla.co.il/item/2956596

Sunflower Day. (n.d.). Retrieved from Gakway Hospice: https://www.galwayhospice.ie/sunflower-story/

The FEED SBS2. (2016, February 16). Every one will die once so we have to get it right, the first time, dying at home - The Feed. Retrieved from YouTube: https://www.youtube.com/watch? $=\mathrm{tUB}$ XnMLhuo

TheMarker. (2018, May 27). Conversation with Roni Zabar. Retrieved from YouTube: https://www.youtube.com/watch?v=K6IngE4qx0M

United Nations Association of Philadelphia. (n.d.). The Sustainable Development Goals 2015 - 2030. Retrieved 5 2, 2017, from United Nations Association of Philadelphia: http://una-gp.org/thesustainable-development-goals-2015-2030

Yalom, I. D. (2008). Staring at the sun : overcoming the terror of death. San Francisco, USA: JosseyBass. 


\section{APPENDIX A}

Some examples of "Memento mori" still life images

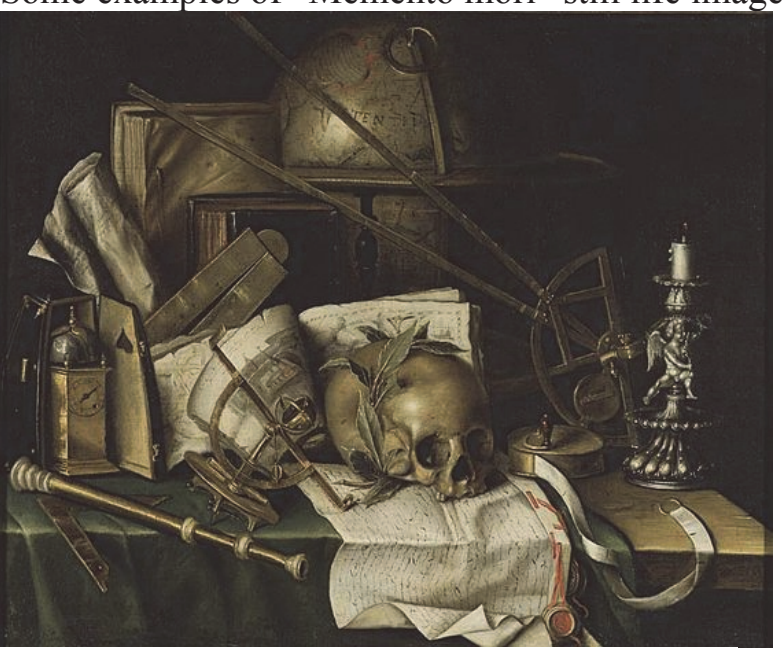

Christian von Thum (1625-1696), Vanitas Still Life with

Astronomical Instruments

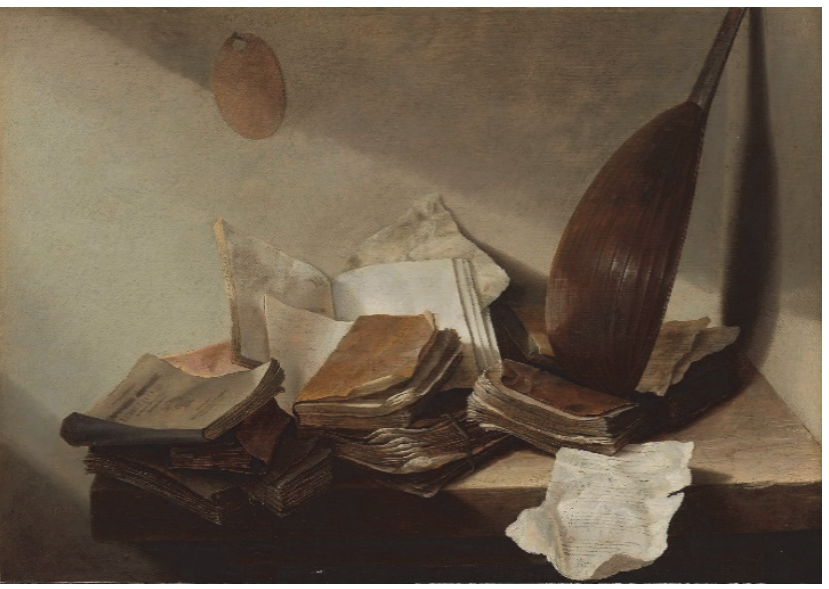

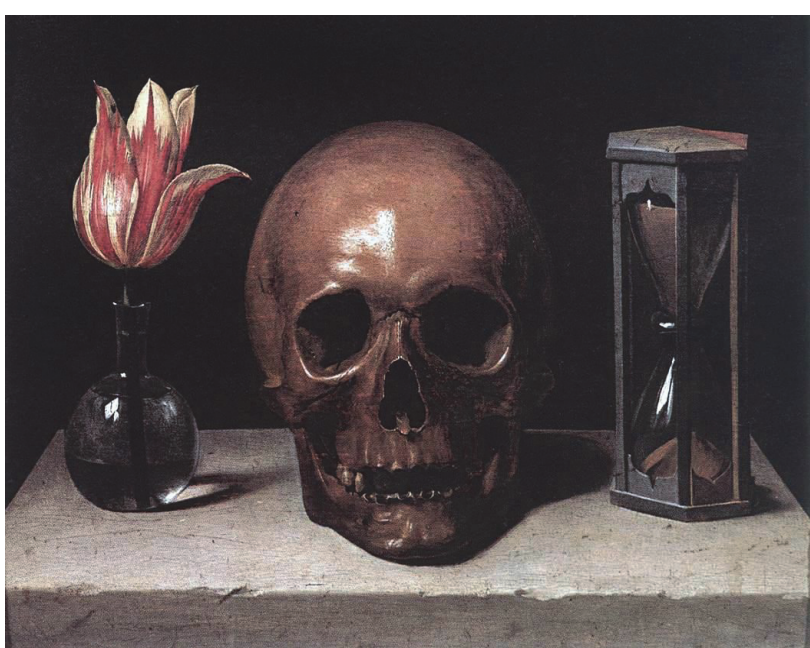

Philippe de Champagne (1602-1674), Still-Life with a Skull (Champagne)

Jan Davidsz. de Heem (1606-1684), Books and a Lute on

a Table 


\section{APPENDIX B}

TABLE 1

INFORMANTS LAYOUT

\begin{tabular}{|c|c|c|c|c|c|c|c|}
\hline Informants & $\begin{array}{l}\text { Profession/ } \\
\text { Role }\end{array}$ & $\begin{array}{l}\text { Age } \\
\text { (Estimated) }\end{array}$ & $\begin{array}{l}\text { Interview } \\
\text { Date }\end{array}$ & $\begin{array}{l}\text { Interview } \\
\text { Place }\end{array}$ & Gender & $\begin{array}{l}\text { Interview } \\
\text { Duration } \\
\text { (Minutes) }\end{array}$ & $\begin{array}{l}\text { Interview } \\
\text { Form }\end{array}$ \\
\hline YS & Psychologist & 37 & 04.12 .2017 & Home & $\mathrm{F}$ & 120 & Frontal \\
\hline DG & $\begin{array}{l}\text { Director of } \\
\text { legal clinic } \\
\text { (This legal } \\
\text { clinic, opened } \\
\text { in 2017, was a } \\
\text { cooperation } \\
\text { between; law } \\
\text { faculty, the } \\
\text { school of } \\
\text { social work, } \\
\text { and medical } \\
\text { school. } \\
\text { Because of } \\
\text { budget issues, } \\
\text { it was closed } \\
\text { in July 2018) }\end{array}$ & & 10.12 .2017 & $\begin{array}{l}\text { Clinic } \\
\text { office }\end{array}$ & F & 120 & Frontal \\
\hline GK & $\begin{array}{l}\text { Undergo } \\
\text { multiple } \\
\text { fertility }\end{array}$ & 40 & 14.11 .2017 & & $\mathrm{~F}$ & 60 & Telephone \\
\hline SR & Researcher & 42 & 11.12 .2017 & & $\mathrm{~F}$ & 60 & Telephone \\
\hline GP & $\begin{array}{l}\text { Physician \& } \\
\text { ALS patient }\end{array}$ & 45 & 22.12 .2017 & $\begin{array}{l}\text { Work } \\
\text { place }\end{array}$ & $\mathrm{M}$ & $\begin{array}{l}\text { Few } \\
\text { minutes }\end{array}$ & Frontal \\
\hline HK & $\begin{array}{l}\text { Manage } \\
\text { support group } \\
\text { of } \\
\text { Accompanied }\end{array}$ & 70 & Dec. 2017 & & F & $\begin{array}{l}\text { Few } \\
\text { minutes }\end{array}$ & Telephone \\
\hline OB & $\begin{array}{l}\text { Accompanied } \\
\text { for a year and } \\
\text { seven months }\end{array}$ & 35 & Dec. 2017 & Cafe & $\mathrm{M}$ & $180 *$ & Frontal \\
\hline EP & $\begin{array}{l}\text { Pensioner \& } \\
\text { biology PHD }\end{array}$ & 70 & 03.01 .2018 & $\begin{array}{l}\text { Work } \\
\text { place }\end{array}$ & $\mathrm{F}$ & 80 & Frontal \\
\hline BP & $\begin{array}{l}\text { Information } \\
\text { librarian }\end{array}$ & 55 & 03.01 .2018 & $\begin{array}{l}\text { Work } \\
\text { place }\end{array}$ & $\mathrm{F}$ & 15 & Frontal \\
\hline ID & $\begin{array}{l}\text { Application } \\
\text { founder }\end{array}$ & 40 & 04.01 .2018 & & $\mathrm{M}$ & 20 & Telephone \\
\hline $\mathbf{R L}$ & $\begin{array}{l}\text { CEO \& } \\
\text { company } \\
\text { founder }\end{array}$ & 50 & 07.01 .2018 & & F & $120 *$ & Telephone \\
\hline IR & $\begin{array}{l}\text { Accompanied } \\
\text { for four and } \\
\text { half months }\end{array}$ & 46 & 13.01 .2018 & Home & $\mathrm{M}$ & 60 & Frontal \\
\hline
\end{tabular}




\begin{tabular}{|c|c|c|c|c|c|c|c|}
\hline Informants & $\begin{array}{l}\text { Profession/ } \\
\text { Role }\end{array}$ & $\begin{array}{l}\text { Age } \\
\text { (Estimated) }\end{array}$ & $\begin{array}{l}\text { Interview } \\
\text { Date }\end{array}$ & $\begin{array}{l}\text { Interview } \\
\text { Place }\end{array}$ & Gender & $\begin{array}{l}\text { Interview } \\
\text { Duration } \\
\text { (Minutes) }\end{array}$ & $\begin{array}{l}\text { Interview } \\
\text { Form }\end{array}$ \\
\hline HB & $\begin{array}{l}\text { Volunteer in } \\
\text { knowledge } \\
\text { transfer } \\
\text { organization } \\
\text { (This } \\
\text { organization; } \\
\text { responds to } \\
\text { the needs; of } \\
\text { the } \\
\text { hospitalized } \\
\text { elderly who } \\
\text { are missing } \\
\text { knowledge. } \\
\text { Most of these } \\
\text { elders, have } \\
\text { language } \\
\text { issues which } \\
\text { make them } \\
\text { helpless in the } \\
\text { liminal space } \\
\text { of their health } \\
\text { and elderly } \\
\text { rights) }\end{array}$ & 67 & 16.01 .2018 & & $\mathrm{~F}$ & 60 & Telephone \\
\hline $\mathbf{E E}$ & Hospice nurse & 55 & 21.01 .2018 & Hospice & $\mathrm{F}$ & 120 & Frontal \\
\hline AK & $\begin{array}{l}\text { Hospice social } \\
\text { worker }\end{array}$ & 50 & 21.01 .2018 & Hospice & $\mathrm{F}$ & 120 & Frontal \\
\hline DS & $\begin{array}{l}\text { Physician \& } \\
\text { Medical } \\
\text { education }\end{array}$ & 50 & 16.04 .2018 & Hospital & $F$ & 90 & Frontal \\
\hline$\overline{E R}$ & $\begin{array}{l}\text { Social worker } \\
\& \text { Manager }\end{array}$ & 60 & 25.04 .2018 & Hospital & $\mathrm{F}$ & 90 & Frontal \\
\hline $\mathbf{L W}$ & $\begin{array}{l}\text { Oncologist } \\
\text { social worker }\end{array}$ & 45 & 25.04 .2018 & Hospital & F & 90 & Frontal \\
\hline TE & $\begin{array}{l}\text { Physician \& } \\
\text { Hospital CEO }\end{array}$ & 45 & 19.06.2018 & Hospital & $\mathrm{F}$ & 30 & Frontal \\
\hline $\mathbf{R R}$ & $\begin{array}{l}\text { Nursing \& } \\
\text { Hematologist }\end{array}$ & 50 & 26.06 .2018 & Hospital & F & 40 & Frontal \\
\hline
\end{tabular}

(* in two sessions) 


\section{APPENDIX C}

Since missing information was identified as a weak point, I observed an information medical centerwhich is staffed by volunteers - to see how they handled information issues. This center provides up-todate information on medical innovations, based on an UpToDate (https://www.uptodate.com/) database. The volunteers' role is to find the requested information and make it accessible, through knowledge or language, to any person who looks for this information.

\section{FIGURE 7 \\ THE INFORMATION MEDICAL CENTER}

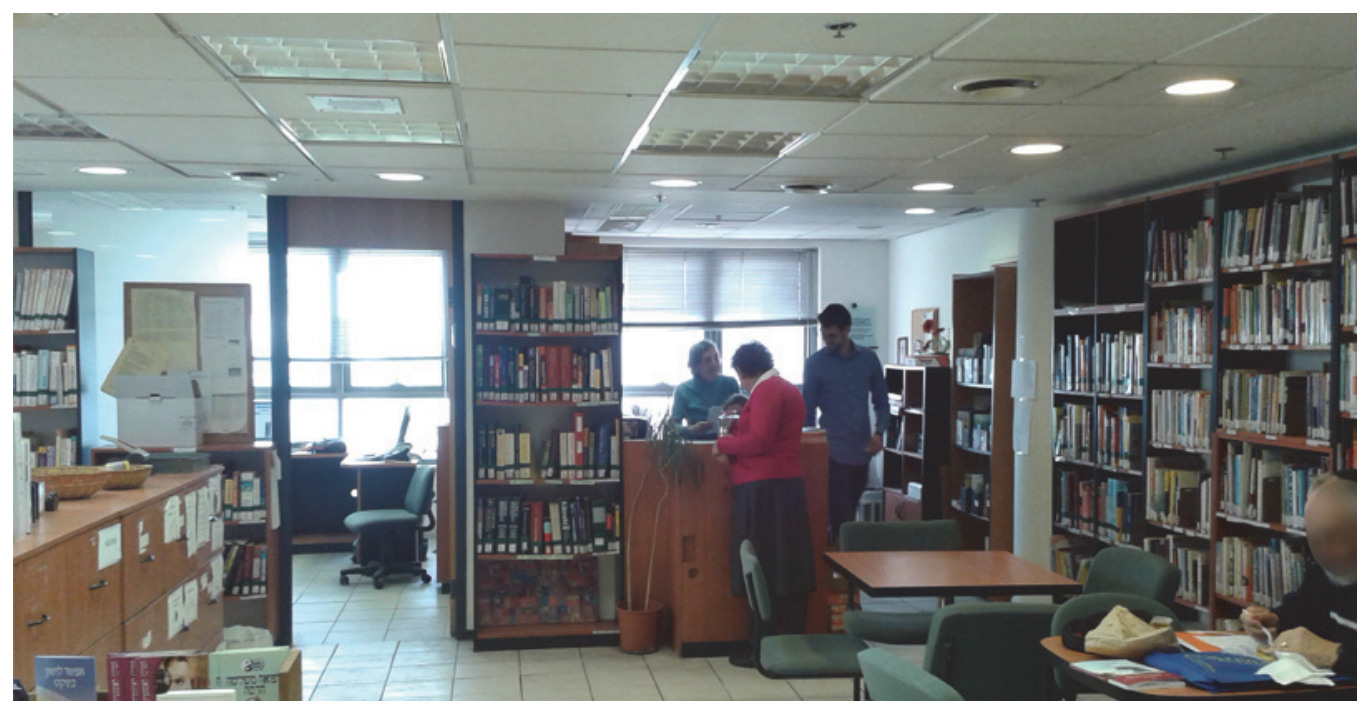

The motivation behind observing oncologist day hospitalization was to see what the daily routine of the Accompanied and their patient looked like. The waiting room was full. Half of the people were Accompanied (Patients were recognized by hospital bracelet. They did not appear to be having treatment side effects). It was difficult and inconvenient in the treatment rooms and radiotherapy room.

TABLE 2

OBSERVATIONS LAYOUT

\begin{tabular}{|l|l|l|}
\hline Observation Place & Observation Date & Observation Duration (Minutes) \\
\hline Oncologist day hospitalization & 24.12 .2017 & 105 \\
\hline Information medical center & 03.01 .2018 & 105 \\
\hline Hospice & 21.01 .2018 & 240 \\
\hline
\end{tabular}




\section{APPENDIX D}

FIGURE 8

FULL EXPERIENCE MAP (LEFT TO RIGHT), HIGHLIGHTED FIFTH PAIN POINT

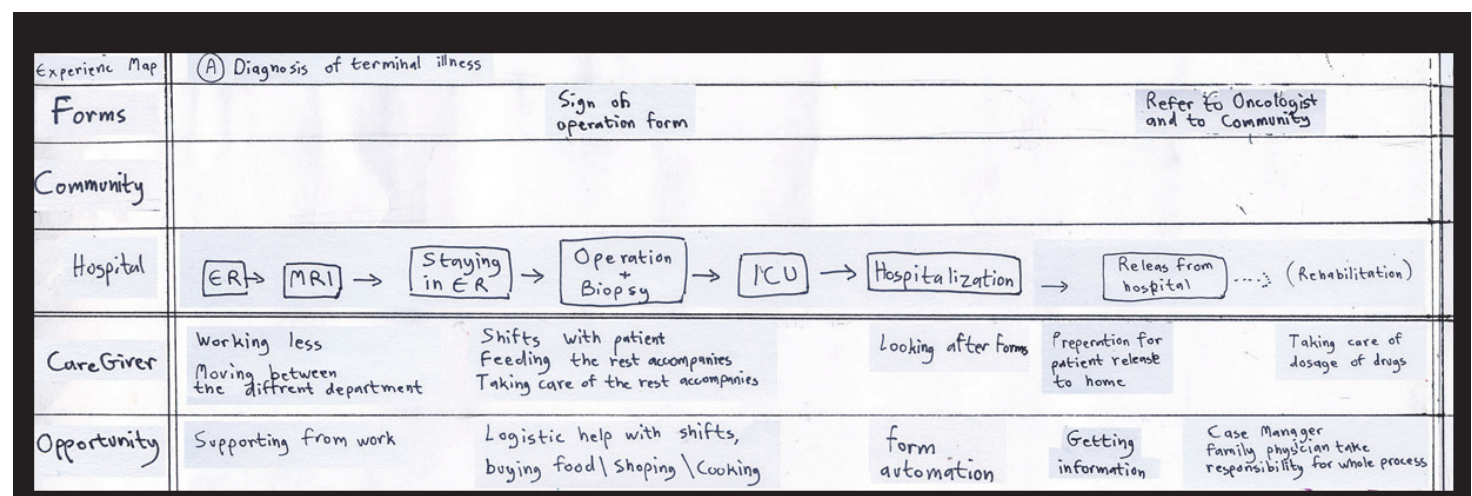
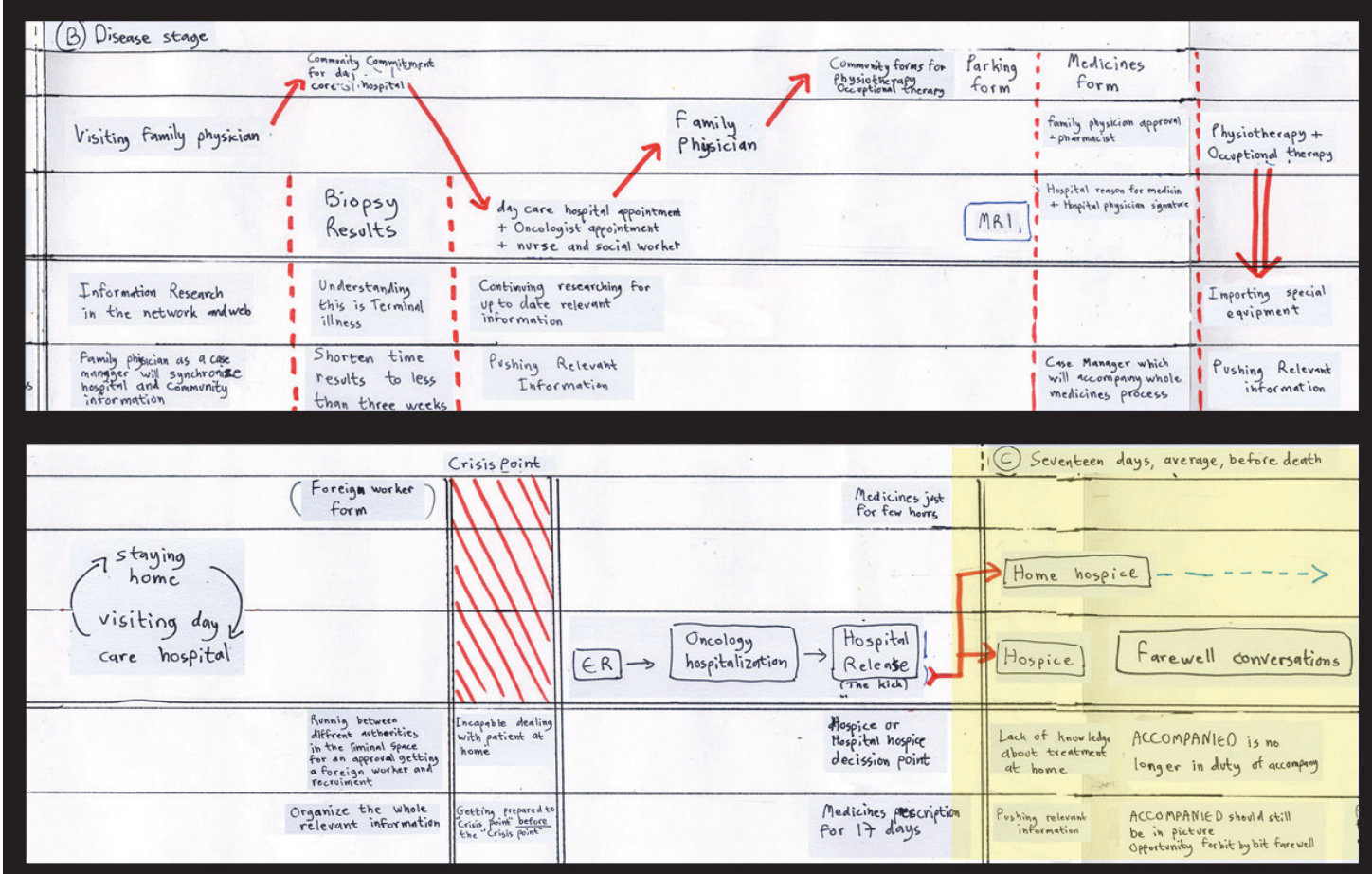

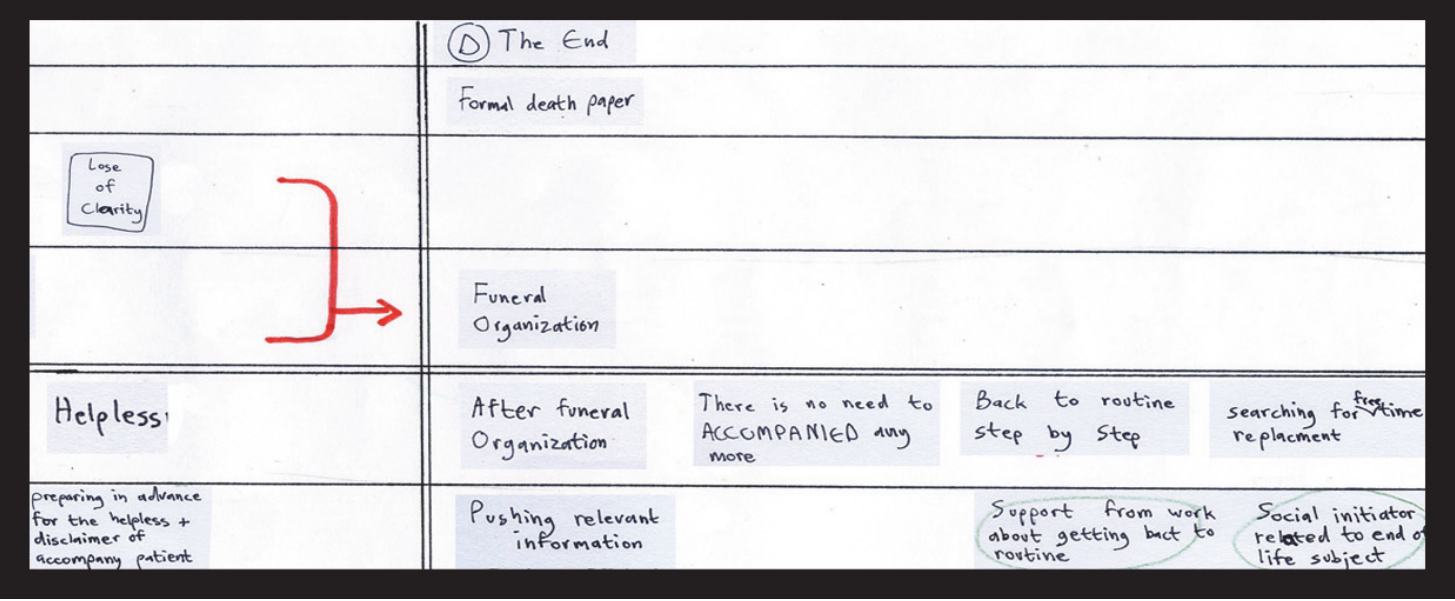




\section{APPENDIX E}

FIGURE 9

FIVE STORYBOARD STRIPS; EACH IS BASED ON ONE PAIN POINT FROM THE EXPERIENCE MAP
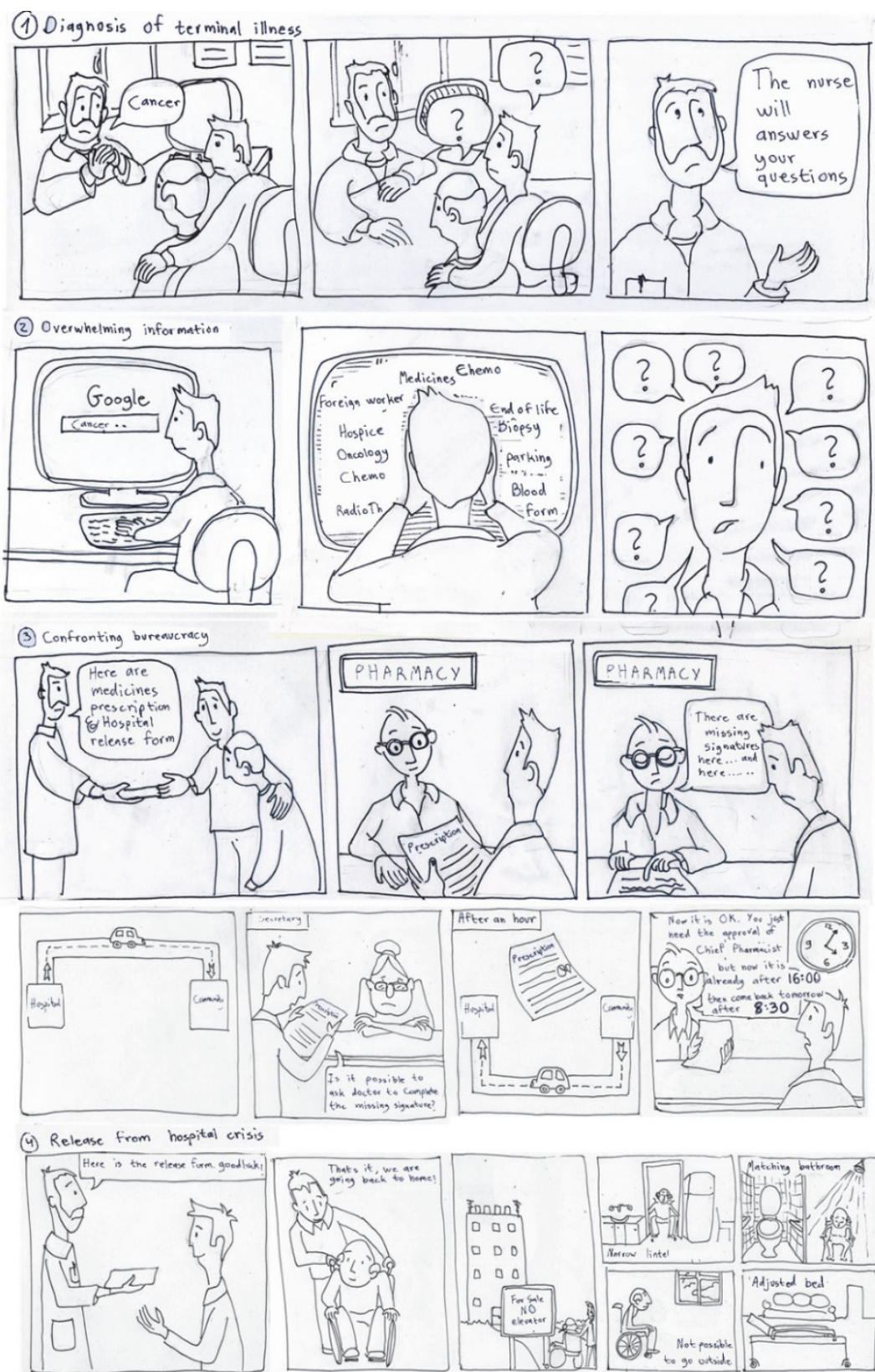

(5) The kich (IR), It days on average, before death
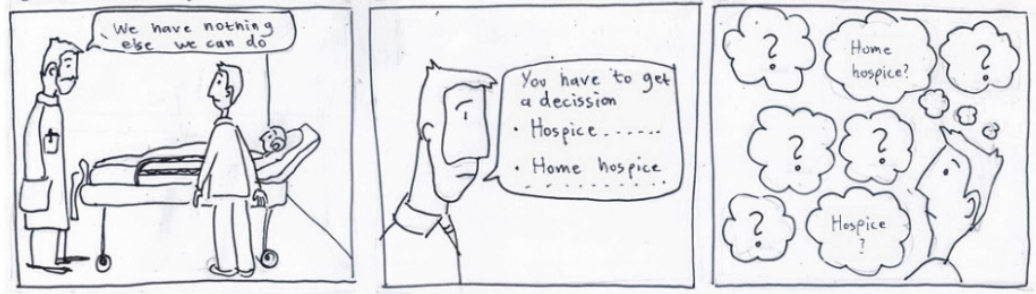

116 Journal of Strategic Innovation and Sustainability Vol. 14(6) 2019 